\title{
Kesejahteraan Psikologis pada Penderita Kusta di Sumberglagah Kec. Pacet. Kab. Mojokerto
}

\section{Psychological Well-Being in Patients of Lepro in Sumberglagah Kec. Pacet. Kab. Mojokerto}

\author{
Jainudin ${ }^{*}$, Fidia Astuti ${ }^{2}$ \\ 1Universitas Islam Negeri Sunan Ampel \\ 2Institut Agama Islam Negeri Kediri \\ *Jainudin1962@yahoo.com
}

\begin{abstract}
Abstrak
Lepra atau kusta adalah penyakit infeksi yang kronis yang dampaknya adalah kecacatan dan keterbatasan. Dengan kondisi tersebut memunculkan berbagai masalah pada diri penderita secara psikologis, penderita akan mendaptkan diskriminasi dan stigma dari masyrakat, namun penderita tetap merasa berbesar hati dan menerima keadaan diri sebagai manusia dihadapan Tuhan adalah sama. Tujuan dari penelitian ini adalah untuk mengetahui gambaran psychological well-being pada penderita Kusta di Sumber Glagah Mojokerto. Subjek penelitian ini adalah sebanyak 3 informan penderita kusta, informan yang digunakan sebagai subjek dalam penelitian ditentukan berdasarkan karakteristik yang ditetapkan oleh peneliti. Metode yang digunakan adalah metode deskriptif kualitatif dengan teknik pengumpulan data observasi, wawancara dan dokumentasi. Instrumen dalam penelitian ini adalah pedoman observasi dan pedoman wawancara. Dimensi yang diteliti meliputi penerimaan diri, hubungan posotif dengan orang lain, kemandirian, penguasaan lingkungan, tujuan hidup dan pertumbuhan personal. Data yang didapatkan selanjutnya dianalisis melewati beberapa tahap reduksi, penyajian data dan dilanjutkan penarikan kesimpulan. Hasil penelitian menunjukan bahwa diawal terjadinya secara klinis dari penyakit kusta ini adalah terlihat pada kulit penderita kusta diantaranya makula berwarna keputihan, rambut alis rontok, kelumpuhan pada kulit muka, terjadi penebalan dikulit muka dan hidup seperti pelana. Masalah yang muncul lainnya adalah setelah subjek didiagnosa kusta maka akan mengalami penurunan kepercayaan diri, merasa malu, kehilangan harapan, dan memiliki harga diri rendah. Diungkap juga semua subjek sebagai anteseden menurunnya kesejahteraan psikologi mereka. Sedangkan peningkatan kesejahteraan psikologis yang menarik di sini adalah terungkap bahwa dimensi penerimaan diri sebagai dimensi pertama yang membantu subjek dalam mencapai dimensi - dimensi kesejahteraan psikologi yang lainnya, yaitu huhungan positif dengan orang lain, kemadirian, penguasaan lingkungan, tujuan hidup dan pertumbuhan personal. Keenam dimensi ini muncul secara tidak bersama - sama, tetapi temuanya sesuai dengan gambaran dimensi.
\end{abstract}

Kata kunci: psychological well-being, penderita kusta, kecacatan.

\begin{abstract}
Leprosy or leprosy is a chronic infectious disease whose impact is disability and limitation. These conditions raise various problems for sufferers psychologically, sufferers will get discrimination and stigma by society because sufferers experience permanent physical disabilities. The purpose of this study was to determine the description of psychological well-being in leprosy patients in Sumberglagah Mojokerto. The subjects of this study were 3 subjects with leprosy, which were used as subjects in the study determined based on the characteristics determined by the researcher. The method used is descriptive qualitative method with data collection techniques of observation, interviews, and documentation. The instruments in this study were observation guidelines and interview guidelines. The dimensions studied include self-acceptance, positive relationships with others, independence, environmental mastery, life goals, and personal growth. The data obtained were then analyzed through several stages of reduction, presentation of data, and followed by drawing conclusions. The results
\end{abstract}


showed that at the beginning of the clinical occurrence of leprosy, leprosy was seen on the skin of people with leprosy including whitish macules, loss of eyebrow hair, paralysis of the facial skin, thickening of the facial skin, and life like a saddle. Another problem that arises is that after the subject is diagnosed with leprosy, they will experience a decrease in self-confidence, feel ashamed, lose hope, and have low self-esteem. It was also revealed that all subjects were the antecedents of declining psychological wellbeing of the subjects. While improving psychological well-being is interesting here, it is revealed that the dimension of self-acceptance as the first dimension helps the subject in achieving other dimensions of psychological well-being, namely positive relationships with others, independence, environmental mastery, life goals, and personal growth. As for other findings, the dimensions of religiosity in achieving psychological well-being and happiness for the three subjects indicate a relationship between the two.

Keywords: psychological well-being, leprosy patients, disability.

\section{Pendahuluan}

Kusta dapat juga disebut dengan Morbus Hansen adalah sebuah penyakit yang menyerang kulit ataupun saraf yang dikarenakan terdapat infeksi microbacterium leprae. Kusta berasal dari bahasa sansekerta ialah Kusta yang memiliki arti sekumpulan gejala penyakit kulit secara umum (Kesehatan Kementrian, 2021). Kusta yang tidak ditangani dengan tepat dan tidak terdeteksi akan secara arah kemajuannya dapat menyerang kulit, saraf anggota gerak dan mata yang mana selanjutnya mengakibatkan kecacatan(Nur Laili, 2017).

Pada saat ini Indonesia masih menghadapi bermacam tantangan dalam pencegahan dan pengendalian penyakit kusta. Data WHO World Health Organization pada tahun 2020 memperlihatkan Indonesia masih memiliki kasus baru kusta nomor tiga terbesar di dunia dengan jumlah kasusnya berkisar 8\% dari kasus dunia. Merujuk pada pencapain program per tanggal 13 Januari 2021, tercatat sebanyak 26 provinsi dan 401 kabupaten/ kota mencapai eliminasi ditandai dengan angka prevalensi kurang dari 1 kasus per 10.000 penduduk. Tetapi masih banyak kantong - kantong kusta di berbagai wilayah di Indonesia. Adapun kasus baru sebanyak 9.061 kusta ditemukan di Indonesia. Dengan angka ini terlihat menurun dibadingkan penemuan kasus kusta pada beberapa tahun terakhir ini, yaitu antara 16.000 - 18.000 kasus baru per tahun. ( p2p.kemkes.go.id: 29 Januari 2021)

Menurut data Profil Kesehatan Indonesia 2021, Pusat Data dan Informasi Ditjen P2P, Kemenkes RI, 20209. Selama tahun 2020 Jawa Timur merupakan satu - satunya provinsi di bagian barat Indonesia dengan angka beban kusta tinggi setelah Papua, Maluku Utara dan Gorontalo (Kesehatan Kementrian, 2021), untuk menangani kasus tersebut Provinsi Jawa Timur telah memiliki 2 rumah sakit kusta yaitu Rumah Sakit Kusta Kediri dan Rumah Sakit Kusta Sumberglagah. Adanya Rumah Sakit itu dijadikan sarana bagi penderita kusta untuk berobat. ( Anggoro \& Qomaruddin, 2019)

Wujud secara klinis dari penyakit kusta ini adalah terlihat pada kulit penderita kusta diantaranya makula berwarna keputihan, rambut alis rontok, kelumpuhan pada kulit muka, terjadi penebalan dikulit muka dan hidup seperti pelana. Papula berwarna agak kemerahan dan terjadi penebalan di daerah tepi. Nodul berwarna kemerahan yang sering terdapat di daerah muka, daun telinga dan badan, kelainan nodul biasa berada pada tipe basah. Ulkus komplikasi luka yang terabaikan karena tidak ada rasa nyeri dan mudah terinfeksi oleh kuman (Sjamsuhidayat, 2011)

Permasalah utama yang dialami oleh individu yang menderita kusta adalah timbulnya kecacatan maupun belum mengalami kecacatan akan mengalami gangguan pada konsep dirinya. Seseorang yang telah didiagnosa kusta maka akan mengalami penurunan kepercayaan diri, merasa malu, kehilangan harapan, dan memiliki harga diri rendah (Setiawan, 2012). Selain itu, stigma negatif di masyarakat terhadap penderita kusta menjadikan penderita dikucilkan bahkan dibuang oleh keluarga dan masyarakat (Scott, 2000). Oleh karena itu keadaan ini membuat penderita kusta semakin susah untuk diterima dan kembali kepada keluarga dan lingkungan masyarakat.

Sumberglagah adalah nama sebuah Dusun yang merupakan salah satu dusun di desa Tanjung Kenongo, Kecamatan Pacet, Kabupaten Mojokerto. Dusun ini dikenal masyarakat luar dengan sebutan kampung kusta karena masyarakat yang tinggal di dusun tersebut mayoritas adalah mantan pasien kusta yang dinyatakan sembuh oleh Rumah Sakit Sumberglagah. Di Dusun Sumberglagah ini terdapat Rumah Sakit Kusta yang mana telah dinobatkan sebagai rumah sakit kusta terbesar di Indonesia. Berbagai macam pasien dari Jawa timur maupun diluar jawa timur menjadi pasien di rumah sakit kusta Sumberglagah untuk mendapatkan pengobatan ( Shobibah, 2014). Mantan pasien kusta yang saat 
ini tinggal di Dusun Sumberglagah dan menempati tanah seluas $51.050 \mathrm{~m}^{\wedge} 2$ tepatnya berada disebelah timur rumah sakit, tahan yang ditempati oleh mantan pasien kusta tersebut disediakan oleh Dinas Sosial Kabupaten Mojokerto (Aulya \& Zain, 2016)

Masalah yang timbul pada penderita kusta sangatlah kompleks. Selain masalah medis, penyakit kusta juga menimbulkan masalah lain yaitu masalah sosial, ekonomi, psikologis, budaya, rasa aman dan ketahanan nasional (Kesehatan Kementrian, 2021). Walaupun pasien kusta telah dinyatakan sembuh dengan menyelesaikan segala pengobatan atau yang dapat dikatakan RFT (Release From Treatment) akan tetapi status penyandang penyakit kusta akan tetap ada dan bawa seumur hidup. Oleh karena itulah yang membuat dasar masalah psikologis pada penderita kusta. Orang yang menderita kusta tentu kesehatannya terganggu, lebih lanjut orang yang menderita kusta juga mengalami gangguan dalam kehidupannya yaitu gangguan kesehajteraan psikologis, gangguan hubungan sosial dan gangguan masalah pada lingkungan (Kementrian Kesehatan RI, 2015). Seperti yang disampaikan oleh Sholehuddin dkk bahwa penyakit kusta adalah penyakit yang dapat menular dapat menimbulkan masalah yang kompleks, masalah yang muncul ini tidak hanya pada fisiknya saja melainkan terjadinya perubahan atau bentuk baru dari fisiknya dan juga masalah pada psikis penderitanya. Adanya rasa malu, merasa kecewa dan menurunnya rasa percaya diri meskipun sudah dinyatakan sembuh dalam masa pengobatan akan tetapi penderita kusta ini akan tetap mendapatkan stigma sebagai penderita kusta oleh masyarakat.(Sholehuddin et al., 2019). Senada dengan yang disampaikan oleh Kataoka dan Nakamura (2005) seseorang penderita kusta mempunyai kesejahteraan psikologi yang rendah.

Kesejahteraan psikologi adalah sebuah istilah untuk mendeskripsikan kondisi kesehatan psikologi pada individu, yang didasarkan pada pemenuhan kriteria fungsi psikologi positif (Ryff, 1989). Selanjutnya Ryff menyatakan bahwa kesejahteraan psikologi merupakan implementasi dan perolehan penuh dari potensi yang dimiliki individu untuk menerima kekurangan dan kelebihan dari diri individu itu sendiri, mampu menciptakan hubungan yang baik dengan orang lain, dapat mengambil keputusan secara mandiri (otonomi), mempunyai penguasaan terhadap lingkungan, memiliki tujuan hidup dan mampu diri secara personal. Dapat disimpulkan bahwa kesejahteraan psikologi adalah menentukan kondisi kesehatan psikologi individu yang berdasarkan pemenuhan kriteria fungsi psikologi positif.

Menurut Hupper (2009) menyatakan bahwa kesejahteraan psikologis yang terganggu dalam waktu yang lama dapat menganggu kemampuan seorang individu dalam kehidupan sehari - hari. Ryff dan Keyes (2002) mengungkapkan kesejahteraan psikologis berpusat pada pemenuhan potensi yang terdapat dalam diri individu.

Dari uraian di atas, terdapat fakta yang menarik yaitu dengan adanya kecacatan fisik yang dimiliki oleh individu tetapi kesejahteraan psikologis individu tersebut meningkat karena adanya keyakinan yang kuat terhadap Tuhan, perubahan pola fikir yang lebih positif dan mampu memahami diri sendiri. Berpijak pada hal tersebut, maka peneliti berupaya untuk mengambarkan perbedaan kesejahteraan psikologiss (psychological well-being) pada penderita kusta di Sumberglagah, Kab Mojokerto.

\section{Metode Penelitian}

Penelitian ini menggunakan pendekatan kualitatif yang hasilnya adalah ungkapan atau kata kata (lisan) dari subjek yang diteliti. Metode yang dipilih adalah deskritif merupakan penelitian yang memberi gambaran secara cermat mengenai individu atau kelompok tertentu tetang keadaan dan gejalan yang terjadi ( Arikunto, 2010). Penelitian ini dilaksanakan pada bulan Juli - Agustus 2021 di Dusun Sumberglagah, Desa Tanjung Kenongo, Kabupaten Mojokerto. Pengambilan subjek menggunakan teknis non-probability sampling dengan teknik purposive. Subjek terdiri dari tiga orang dengan karakteristik penderita kusta yang masih menetap di kampong kusta, berusia antara 40 - 65 tahun, menderita penyakit kusta lebih dari 15 tahun.

Teknik pengumpulan data menggunakan observasi, wawancara dan dokumentasi. Guna mendapatkan data yang reliabel dan valid, penelitian ini menggunakan triangulasi sumber dan teknik. Triangulasi sumber dilakukan dengan melakukan wawancara mendalam pada eks penderita kusta di Dusun Sumberglagah dan tokoh masyarakat di Desa Tanjung Kenongo. Sedangkan triangulasi teknik yang dilakukan yaitu menggunakan teknik wawancara dan observasi. Proses analisis data dilakukan bertahap yaitu meliputi pengumpulan data mentah, reduksi data, penafsiran data, dan data kemudian dianalisis dengan penarikan kesimpulan. 


\section{Hasil Penelitian}

Karakteristik subjek

Berdasarkan hasil pada tabel 1, menunjukan bahwa subjek penelitian telah menderita kusta selama 15 sampai 46 tahun. Tentunya bukan waktu yang singkat untuk menerima kecacatan dalam dirinya. Selain itu subjek penelitian memilih menetap di kampung kusta karena merasa minder jika kembali ke tempat asalnya dan merasa berbeda dengan orang lain, dua diantaranya berasal dari Kabupaten Mojokerto tetapi dari kecamatan berbeda. Semua yang tinggal di sana berada dalam satu kompleks, menjadi keluarga baru yang senasib dan seperjuangan.

Tabel 1. Karakteristik Subjek

\begin{tabular}{lllll}
\hline Subjek Penelitian & Usia & Inisial & Lama Menderita Kusta & Asal \\
\hline Subjek 1 & 56 & SY & 26 Tahun & Kab. Mojokerto \\
Subjek 2 & 42 & I & 15 Tahun & Kota Surabaya \\
Subjek 3 & 64 & DR & 46 Tahun & Kab. Mojokerto \\
\hline
\end{tabular}

Selain itu, alasan subjek tidak meninggalkan kampung kusta di Dusun Sumberglagah adalah adanya bantuan dan fasilitas yang diberikan oleh Dinas Sosial Kabupaten Mojokerto yaitu menempati tanah seluas $51.050 \mathrm{~m}^{\wedge} 2$ tepatnya berada disebelah timur rumah sakit (Aulya \& Zain, 2016) serta adanya bimbingan keagamaan dari tokoh agama misalnya dari UIN Sunan Ampel Sby dan bimbingan sosial dari Lembaga Sosial Masyarakat lainya.

Ada beberapa tema jawaban dari ketiga subjek penelitian setelah melakukan sesi wawancara, Tabel 2 menjelaskan jawaban subjek dari pertanyaan - pentanyaan yang diajukan oleh peneliti. Seperti yang dipaparkan pada table di bawah ini:

Tabel 2. Pertanyaan dan Jawaban subjek

\begin{tabular}{clrlll}
\hline Aspek & \multicolumn{2}{c}{ Tema } & \multicolumn{2}{c}{ Subjek 1 } & \multicolumn{2}{c}{ Subjek 2 } & \multicolumn{1}{c}{ Subjek 3 } \\
\hline Penerimaan diri & Bersikap & positif & Merasa & Menerima takdir & Menyadari \\
& terhadap diri dan & bersyukur masih & dari Tuhan, dalam & keadaanya yang \\
& mengakui & dan & diberikan umur, & kehidupan sudah cacat, & dan \\
& menerima berbagai & dan & bisa beradaptasi berusaha tetap \\
& aspek dalam hidup. & kehidupannya & dengan sesama berkerja & \\
& & & seperti manusia & penderita maupun semampunya. \\
& & & pada umumnya & masyarakat.
\end{tabular}

Hubungan positif Mampu mencintai Memiliki Istri, Mencintai orang Memiliki Istri, dengan orang lain. orang lain, pada hubungan lain, dalam pada hubungan memuaskan dan dengan orang hubungan dengan dengan orang saling percaya lain awal sakit orang lain Tidak lain tidak ada dengan orang lain. dikucilkan, terdapat masalah, masalah terkait namun dengan karena sudah hubungan dengan mandiri secara dengan orang bimbingan dan ekonomi. Cara lain, cara berobat bisa mempercayai jika mempercayai jika menerima memberikan mau diajak keadaan diri. pekerjaan. bersalaman dan Cara menyapa mempercayai jika sudah mau makan bersama

Memiliki afeksi dan Persaudaraan di rasa empati yang sini kuat baik kuat. penderita maupun warga

Kemandirian

Mampu mengatur Jika mengatur diri sendiri,

menjadi lebih
Membantu

sebisanya dengan suka rela

Memiliki jalan hidup sendiri, dan
Ikut serta menolong semampunya biasanya dalam hal non material

Selalu taat dengan aturan - 
Penguasaan

lingkungan

Tujuan hidup

\section{Pertumbuhan personal}

menolak tekanan baik maka akan sosial dan mampu patuh, dan mengevaluasi diri berusaha sendiri.

Mampu
memanipulasi
keadaan sehingga
sesuai dengan
kebutuhannya, dan
mampu
mengembangkan
diri.

melakukan

introspeksi diri karena kecacatan yang terjadi pada saya.

Menghindari, cara

mengembangkan diri dengan mengikuti program pelatihan pembinaan sini.

$\begin{array}{lr}\text { Mempunyai } & \text { rasa } \\ \text { keterarahan } & \text { hidup, } \\ \text { memiliki } & \\ \text { keberartian } & \text { dalam } \\ \text { hidup, } & \text { dan } \\ \text { mempunyai } & \text { target } \\ \text { pencapaian. } & \end{array}$

Optimis mau menyekolahkan anak sampai sarjana, prinsip tetap berusaha semampunya dan menerima

keadaan saya ini, tetap berada di sini belum mau kembali di desa asal.

Keterbukaan

terhadap

pengalaman, perasaan yang ingin terus berkembang dan mampu melihat peningkatan diri sendiri

\section{Tetap berobat} sesuai petunjuk dokter, melakukan pekerjaan yang bisa seperti berdagang.

$\begin{array}{lrlr}\text { cara intropeksi } & \text { aturan baik yang } \\ \text { diri dengan } & \text { dibuat, cara } \\ \text { memintak maaf } & \text { indtopeksi } & \text { diri } \\ \text { jika menyikiti } & \text { dengan } & \text { tidak } \\ \text { orang lain. } & \begin{array}{l}\text { menyakiti } \\ \text { hati }\end{array} \\ & \text { orang lain. } & \end{array}$

Memahami perbedaan, cara mengembangkan diri dengan menyalurkan hobi Tetap menjaga komunikasi, mengembangkan bermusik. diri bertani ubi dan berternak

\begin{tabular}{|c|c|}
\hline $\begin{array}{l}\text { Pengen punya } \\
\text { usaha sendiri, } \\
\text { prinsip saya } \\
\text { selama masih ada } \\
\text { Allah insyallah } \\
\text { semuanya baik2 } \\
\text { saja, dan sudah } \\
\text { menerimaan } \\
\begin{array}{l}\text { keadaan saya } \\
\text { yang cacat ini. }\end{array}\end{array}$ & $\begin{array}{lr}\text { Ingin } & \text { pulang } \\
\text { kedesa } & \text { asal, } \\
\text { prinsip hidup } \\
\text { berkerja } & \text { dengan } \\
\text { halal } & \text { bisa } \\
\text { memberi nafkah } \\
\text { keluarga, dan } \\
\text { menerima } \\
\text { keadaan } \\
\text { berusaha dengan } \\
\text { meminum obat } \\
\text { dan terus berdoa } \\
\text { pada Allah. } \\
\text { Berkonsultasi } \\
\text { dengan dokter } \\
\text { dan minum obat, } \\
\text { tetap berkerja } \\
\text { semampunya }\end{array}$ \\
\hline
\end{tabular}

Konsep dari kesejahteraan psikologis pada penderita kusta dapat disimpulkan menjadi 7 tema besar yaitu bersikap positif terhadap diri, mengakui dan menerima berbagai aspek dalam hidup, mampu mencintai orang lain, memuaskan dan saling percaya dengan orang lain, memiliki afeksi dan rasa empati yang kuat, mampu mengatur diri sendiri, menolak tekanan sosial dan mampu mengevaluasi diri sendiri, mampu memanipulasi keadaan sehingga sesuai dengan kebutuhannya, dan mampu mengembangkan diri, mempunyai rasa keterarahan hidup, memiliki keberartian dalam hidup, dan mempunyai target pencapaian serta adanya keterbukaan terhadap pengalaman, perasaan yang ingin terus berkembang dan mampu melihat peningkatan diri sendiri. Tema tersebut disesuaikan dengan temuan penelitian dari dimensi - dimensi kesejahteraan psikologis. Berdasarkan temuan tema tersebut dapat disimpulkan bahwa ketiga subjek penelitian memiliki kesejahteraan psikologis yang sama.

\section{Pembahasan}

Dari hasil proses wawancara yang dilaksanakan peneliti telah menggali konsep dari kesejahteraan psikologi yang akan dijabarkan sesuai dengan dimensi - dimensi kesejahteraan psikologis yaitu penerimaan diri, hubungan dositif dengan orang lain, kemandirian, penguasaan lingkungan, tujuan hidup dan pertumbuhan personal. 


\section{Penerimaan diri}

Bersikap positif terhadap diri, mengakui dan menerima berbagai aspek dalam hidup menurut Ryff dan Mayer (1989) menandakan kesejahteraan psikologi yang tinggi, individu yang memiliki penerimaan diri yang baik ditandai dengan bersikap positif maupun negatif terhadap diri. Ketiga subjek telah menerima keadaan dirinya saat ini dengan keadaan fisik yang cacat dan stigma masyarakat terhadap penderita kusta walaupun sudah dinyatakan sembuh.

"Saya merasa bahwa saya sebagai makhluk ciptaan Tuhan walaupun kodisi saya sakit saya tetap bersyukur dan biasa saja saya tetap bekerja saya sadar kalu saya sakit maka mencari pekerjaan yang bisa saya lakukan."(S1)

"Biasa saja saya tetap bekerja saya sadar kalu saya sakit maka mencari pekerjaan yang bisa saya lakukan. Saya merasa ini kesalahan saya waktu sakit pertama saya tidak telaten minum obat sehingga sepertiini ya.... sudah" (S3)

Selanjutnya, menerima berbagai aspek dalam hidup baik itu positif maupun negative di masa lalu mapun masa sekarang dengan cara menerima keadaan saat ini yang cacat dan tetap berusaha menjalankan aktifitas secara normal seperi orang pada umumnya, melalui bimbingan keagamaan dan sosial yang dilakukan oleh tokoh masyarakat membuat diri tidak minder.

"Saya sadar saya cacat ini sudah taqdir"

"Saya menerima keadaan ini saya tidak minder tidak berkecil hati. Dulu sempat drop tetapi setelah lama berkegiatan social dengan bimbingan para tokoh saya bahagia saja, dan kehidupan saya biasa seperti orang-orang umumnya normal saja"(S2)

Hal senada juga disampaikan oleh Shaver dan Freedman (dalam Harlock, 1994) menyatakan sikap menerima pada orang lain dipengaruhi oleh sikap menerima diri yang ditimbulkan dari penyesuian individu mapun penyesuaian sosial yang baik, artinya kebahagiaan tergantung pada sikap menerima dan menikmati keadaan orang lain dan apa yang dipunyainya.

\section{Hubungan positif dengan orang lain}

Para subjek penelitian menyampaikan alasan tetap menjaga hubungan positif dengan orang lain, dengan ciri mampu mencintai orang lain, memuaskan dan saling percaya dengan orang lain. Penting sekali menjaga hubungan tersebut karena pada subjek 1 dan subjek 3 memiliki istri dan kelurga yang tetap harus dijaga dan disejahterakan. Sedangkan subjek ke 2 belum menikah. Selanjutnya untuk menjaga hubungan dengan orang lain ketiga subjek melakukannya dengan cara tetap bersikap baik dan tidak mencari masalah, cara mempercayai orang lain yaitu ketika orang tersebut mau menyapa, berjabat tangan dan mau makan bersama.

"Saya punya istri dan istri saya sehat dan cantik tidak seperti saya, Awal saya sakit saya terkucilkan tetapi dengan adanya sosialisasi tentang kusta lama kelama tidak ada masalah dengan orang sehat dan berteman dengan para warga yang lain dan dengan sapaan, berjabat tangan dan mau makan bersama dengan demikian berarti orang itu sangat menghargai keadaan saya akhirnya saya senang dan saling hirmat bahkan saling berkorban"(S1 dan $\mathrm{S} 2)$

"Punya pasangan tapi sering masalah karena ketika saya ajak pergi ikut saya, dia tidak mau" (S3)

Selanjutnya ketiga subjek memiliki afeksi dan rasa empati yang kuat dengan menolong masyarakat disekitar kampung kusta tersebut dengan cara membantu secara non material berupa bantuan tenaga atau pikiran. Subjek 2 ini memiliki toko kelontong jadi bisa membantu orang sekitar misalnya memberikan hutangan uang.

"Persaudaran orang kusta itu kuat bahkan tidak hanya warga sini bahkan penderita kusta se Indonesia. Kita saling tolong menolong" (S1)

"Memberi perkerjaan yang ringan bisa dipercaya saya tambah sampai pada saya betul - betul percaya dengan cara memberi bantuan pekerjaan semampu dia dan saya. Saya selalu membantu semampu saya bahkan akhir akhir ini karena saya bantu ada yang mencintai saya”(S2)

"Saya berusaha menolong sesuai dengan kemampuan saya biasanya saya bantu tenaga karena ekonomi saya kurang lancar. Bahkan saya sering memndapat bantuan dari orang lain, hehe"(S3)

Subjek 2 dan subjek 3 mengembangkan diri dengan cara mengembangkan hobi bermusik, bertani ubi dan berternak sapi.

\section{Kemandirian (otonomi)}

Ciri - ciri dari kemandirian atau otonomi yang baik adalah mampu mengatur diri sendiri, menolak tekanan sosial dan mampu mengevaluasi diri sendiri untuk mengikuti cara berpikir dan berpikir (Ryff dan Keyer, 1989). Pada ketiga subjek menunjukan adanya otonomi yang baik ditandai 
dengan pencapaian subjek dalam mengatur dirinya sendiri. Pada subjek kedua memiliki usaha sendiri jadi secara ekonomi sudah mandiri.

"Kalau mengatur lebih baik dan menguntungkan saya mau" (S1)

"Saya mempunyai jalan hidup sendiri." (S2)

"Mengatur sesuai dengan aturan saya selama ini selalu taat, Ada yang tidak saya ikuti kalau mengatur yang tidak sesuai dengan kemampuan saya” (S3)

Sedangkan untuk tekanan sosial ketiga subjek juga sependapat bahwa menjaga diri untuk tidak menyakiti orang lain dan menjaga tidak terlibat masalah, selanjutnya untuk mengevaluasi diri subjek 2 dan subjek 3 merenungi apa yang terjadi dan meminta maaf jika telah salah dalam berperilaku.

"Saya menyadari saya cacat maka saya berusaha untuk instrospeksi diri" (S1)

"Saya berusaha untuk tidak menyakiti orang lain dan kalau terpaksa ya minta maaf"(S2)

"Saya berusaha untuk tidak menyakiti orang lain"(S3)

\section{Penguasaan lingkungan}

Penguasaan lingkungan yang baik ditandai dengan mampu memanipulasi keadaan sehingga sesuai dengan kebutuhannya, dan mampu mengembangkan diri. Terlihat pada subjek 2 dan 3 mampu memanipulasi dengan memahami dan menjaga komunikasi dengan orang lain, tetapi pada subjek 1 mampu membaur dengan masyarakat sekitar tempat tinggal. Selanjutnya untuk kemampuan mengembangkan diri masing - masing subjek berbeda - beda kegiatan, pada subjek 1 memilih mengikuti bimbingan dan pembinaan keagamaan, subjek 2 memilih mengembangkan diri dengan menyalurkan hobinya bermusik, dan untuk subjek 3 memilih untuk berternak dan bertani.

"Menghindari dan tetap dirumah bila tidak cocok, tetapi tetap mengikuti kegiatan hanya saya menghindari konflik. Masyarakat sini sering didatangi oleh orang yang peduli kepada kita sering diberi pelatihan agama, usaha dan mengolah lingkungan" (S1)

"Memahami perbedaan sehingga saya tidak terisolasi, Saya bisa music saya dengan teman saya membuat kelompok music tetapi hanya untuk masyarakat sekitar sampai saat ini belum ada orang lain yang nanngap mungkin karena takut ketularan." (S2)

"Berusaha tetap berkomunikasi dengan lingkungan sekitar. Saya bertani dan beternak sampai sekarang saya memelihara sapid an bertani ubi mengerjakan tanah rumah sakit" (S3)

Pada aspek penguasaan lingkungan adalah individu mampu untuk memilih dan menciptakan lingkungan yang diinginkan dan sesuai kebutuhan, dimana hal tersebut dapat diartikan sebagai salah satu karakteristik kesejakteraan psikologis.

\section{Tujuan hidup}

Ketiga subjek ini mampu menunjukan tujuan hidup, yaitu mempunyai rasa keterarahan hidup, memiliki keberartian dalam hidup, dan mempunyai target pencapaian. Subjek 1 menceritakan bahwa terlanjur cacat tetap senang dan optimis. Seperti berkeinginan anaknya bisa mengenyam pendidikan tinggi dan tidak diisolasi oleh masyarakat.

"Saya pingin anak saya kuliah biar tidak seperti saya. Keluarga saya tidak diisolasi. Masa lalu saya kelam ketika pertama kali saya kena sakit kusta bahkan strees berbulan-bulan tetapi bersyukur ada seorang teman yang membantu untuk dibawa disini dan diobati dirumah sakit akhrnya sembuh tapi sudah terlanjur cacat saya tetap senang dan optimis. Selama saya berusaha pasti tuhan akan memberi jalan terbaik untuk saya" $(\mathrm{S} 1)$

Subjek kedua menjelaskan arah menentukan tujuan hidupnya dengan cara mengembangkan uasah toko kelontong, tidak minta - minta dijalan, dan juga bahwa sudah menerima kecacatan yang saat ini menimpah dirinya, karena subjek 2 ini lulusan pondok pesantren yang diajakan agama lebih dalam maka tingkat kepasrahanya cukup tinggi.

"Saya ingin punya toko dirumah biar tidak meminta-minta saya malu minta minta tapi gimana terpaksa. Biasa saja sejak sakit sampai sekarang saya tetap menerima karena saya dari pesantren sudah pernah dengar istilah judam wal baros itu penyakit zaman nabi Isa. Toh akhirnya ada obatnya. Saya kira Allah tetap sayang sama kita walaupun keadaan saya seperti ini ada hikmahnya nyatanya saya masih hidup dan diberi rejeki melalui saya mengajar ngaji dan saya tidak bekerja hanya merawat masjid dan kegiatan disini"(S2)

Selanjutnya subjek ketiga pada hakehatnya sudah menerima keadaan yang dialami saat ini, dulu sempat ke alternative melakukan terapi tetapi bertambah parah kustanya, dan sekarang sudah sehat meskipun cacat. Subjek ketiga ini juga memiliki semangat berkerja yang tinggi karena tetap memberikan nafkah untuk keluarganya. Kondisi tersebut menunjukan perbaikan dalam tujuan hidup subjek (Ryff dan Keyes, 1989). 
"Saya pingin kembali/sambang ke desa saya, kalau sudah mau menerima keadaan saya sia. Semua ini kehendak Tuhan yang penting saya usaha dan ikhtiar untuk berobat kemana mana ke dukun dan lain . Alhamdulillah disini ada rumah sakit khusus kusta akhirnya bisa terobati dan ditampung disini dan bisa berkeumpul bersama dengan orang senasip sama sama kusta. Yang penting saya bekerja yang halal untuk memberi nafkah keluarga"(S3)

\section{Pertumbuhan personal}

Pertumbuhan persona juga dipengaruhi oleh adanya keterbukaan terhadap pengalaman, perasaan yang ingin terus berkembang dan mampu melihat peningkatan diri sendiri. Subjek 1 dan 2 menunjukan pegalaman selama menderita kusta awalnya sulit beradaptasi, seiringi berkembangnya waktu dapat menerima keadaan untuk saat ini tetap rutin minum obat dokter jika dirasa gejala sakitnya sedang kambuh. Perasaan yang ingin berkembang pada subjek 1 terlihat peningkatan hal tersebut dari kegiatan yang dilakukan setiap hari yaitu berdagang yang sebelumnya meminta - minta, ngemen dan kerja di pabrik. Subjek 2 karena sudah memiliki toko kelontong sendiri maka secara ekonomi lebih stabil, lebih suka mengikuti kegiatan keagamaan, Subjek 3 berkerja semaksimalnya (serabutan). Ketiga subjek tetap berkonsultasi dengan dokter jika badan merasa tidak stabil.

"Saya beorbat biar sehat mengikuti petunjuk dokter. Pertama dulu bingung apa yang bisa saya lakukan terpaksa saya ngemis kemudian ngamen dan kerja pabrik dipecat karena kerja tidak maksimal akhirnya saya dagang." (S1)

"Saya berdoa dan berobat kepada dokter siapa yang menunjukkan obat pada saya saya coba. Saya membuat kegiatan keagamaan Alhamdulillah banyak yang ikut saya dibimbing oleh dosen IAIN Surabaya. Untuk berkerja iya saya kerja dirmh jaga toko bu..." (S2)

"Saya konsultasi pada orang lain Tanya Tanya bagaimana saya saya ini seperti ini akhirnya saya diantar disini. Bekerja dan bekerja sebisanya yang penting dapat memnghidupi keluarga anak bisa sekolah wallaupun cacat saya bisa menyekolahkaan anak saya sudah senang" (S3)

Sehingga pertumbuhan personal pada penderita kusta ini lebih kepada bagaimana sebagai penderita kusta dapat bangkit dari keterpurukan dan mampu merajut asa kembali dengan berkerja, beribadah, mengebangkan hobi dan mengisi hari - hari dengan kegiatan - kegiatan positif.

\section{Kesimpulan}

Berdasarkan temuan penelitian, dapat disimpulkan bahwa kesejahteraan psikologis semua subjek mengalami perubahan akibat kusta yang dialami oleh penderita. Diawal terjadinya secara klinis dari penyakit kusta ini adalah terlihat pada kulit penderita kusta diantaranya makula berwarna keputihan, rambut alis rontok, kelumpuhan pada kulit muka, terjadi penebalan dikulit muka dan hidup seperti pelana. Masalah yang muncul lainnya adalah setelah subjek didiagnosa kusta maka akan mengalami penurunan kepercayaan diri, merasa malu, kehilangan harapan, dan memiliki harga diri rendah. Diungkap juga semua subjek sebagai anteseden menurunnya kesejahteraan psikologi mereka. Sedangkan peningkatan kesejahteraan psikologis yang menarik di sini adalah terungkap bahwa dimensi penerimaan diri seperti bersikap positif maupun negatif terhadap diri yaitu stigma oleh masyarakat terhadap dirinya yang cacat, dan telah menerima masa lalu mereka yang kelam akibat peribahan fisiknya. Penerimaan diri ini sebagai dimensi pertama yang membantu subjek dalam mencapai dimensi - dimensi kesejahteraan psikologi yang lainnya, yaitu huhungan positif dengan orang lain, kemadirian, penguasaan lingkungan, tujuan hidup dan pertumbuhan personal. Keenam dimensi ini muncul secara tidak bersama - sama, tetapi temuan tersebut sesuai dengan gambaran dimensi yang diungkap oleh Ryff dan Keyes (1989). Ada temuan lain yang muncul yaitu dimensi religiusitas dalam pencapaian kesejahteraan psikologis dan kebahagiaan ketiga subjek menunjukan adanya keterkaitan diantara keduanya.

\section{Daftar Pustaka}

Arikunto, Suharsimi. (2010). Prosedur Penelitian Suatu Pendekatan Praktik. Jakarta : Rineka Cipta Anggoro, Qomarudin. (2019) Iteraksi sosial Asosiatif eks penderita kusta di dussun sumberglagah, Kabupaten Mojokerto. Jurnal The Indonedian Journal Of Public helth, Vol 14, No 1 Juli 2019 hal $130-140$ 
Aulya, N. A., and Zain, I. M. 2016. Kajian Faktor-Faktor Eks Penderita Kusta Memilih Tinggal Di Dusun Sumberglagah Desa Tanjung Kenongo Kecamatan Pacet Kabupaten Mojokerto. Swara Bhumi, 3(3).

Friedman, Marilyn M. (2003). Keperawatan Keluarga Teori dan Praktek. Jakarta : EGC.

Hurlock, E. B. 1999. Psikologi Perkembangan: Suatu Pendekatan Sepanjang Ruang Kehidupan. Edisi 5. Jakarta: Erlangga.

Kataoka, M., dan Nakamura, H. (2005). Psychological well-being and associated factors mong elderly hansen"s disease patient in leprosaria. Environmental health and preventive medicine. 10, 201207

Kementerian Kesehatan RI, 2015. Profil Kesehatan Indonesia 2014. Jakarta: Kementerian Kesehatan Republik Indonesia.

Kesehatan Kementrian. (2021). PROFIL KESEHATAN INDONESIA TAHUN 2020. In M. Boga Hardhana, S.Si, Ms. P. Farida Sibuea, SKM, \& M. Winne Widiantini, SKM (Eds.), Profil Kesehatan Indonesia 2020. Kementerian Kesehatan Republik Indonesia.

Nur Laili, A. F. (2017). Hubungan Dukungan Keluarga Dan Pengetahuan Terhadap Perawatan Diri Penderita Kusta Di Puskesmas Grati Tahun 2016. The Indonesian Journal of Public Health, 12(1), 13. https://doi.org/10.20473/ijph.v12i1.2017.13-26

Mu'mainah. (2019). Peran Self-Sigma terhadap kesejahteraan psikologi pada mantan Penderita Kusta Di Sumatera Selatan. Skripsi. Universitas Sriwijaya

Nasrudin. (2015). Hubungan dukungan keluarga dengan harga diri penderita kusta di puskesmas Jogoloyo Kecamatan Sumobito Kabupaten Jombang. Jurnal Edu Health, Vol. 5 No.1 April 2015

Sholehuddin, S., Nulhaqim, S. A., \& Raharjo, S. T. (2019). Dukungan Keluarga Bagi Penderita Kusta Di Kota Cirebon. Prosiding Penelitian Dan Pengabdian Kepada Masyarakat, 6(1), 81. https://doi.org/10.24198/jppm.v6i1.22820

Ryff, C.D. (1995). Psychological well-being in adult life. Sage publication. Doi: 10.1111/14678721.ep10772395.

Ryff, C.D. (1989). Happiness is everything, or is it? Explorations on the meaning of psychological wellbeing. Journal of personality and social psychology. 57(6), 1069-1081.

Setiawan, Yahmin. (2012). Pengobatan Tuntas, Sembuh Dari Kusta. Di akses 14 januari 2013.

Sjamsuhidayat R, dkk. (2011). Buku Ajar Ilmu Bedah. Jakarta : EGC

Scott, J. (2000). Psychosocial need of leprosy patient.Leprosy Review, 71. 486-491

http://p2p.kemkes.go.id/pravalensi-kusta-pada-anak-tinggi-temukan-kasusnya-periksa-kontak-danobati-sampai-tuntas/ 